\title{
The Terezín Requiem (Terezínské Rekviem)
}

\author{
Author: Josef Bor
}

First Published: 1963

Translations: English (The Terezín Requiem, 1963); German (Theresienstädter Requiem, 1963); Danish (Theresienstadt - koncerten, 1965); Dutch (Requiem Theresienstadt, 1965); French (Le requiem de Terezin, 1965); Hebrew (Rekviem I'Terezienstadt, 1965); Italian (Il "Requiem” di Terezín, 1965); Norwegian (Rekviem i Terezín, 1965); Portuguese (Requiem em Terezín, 1966); Swedish (Requiem i Theresienstadt, 1968); Polish (Terezińskie rekwiem, 1978); Greek (To Rékviem tis Terezín, 1980).

Radio Adaptation: Terezínské rekviem, Czechoslovak Radio, recorded 1964, published 2016, dramatisation Karel Valtera and Dagmar Hubená, director Jiř́i Roll.

About the Author: Josef Bor (1906-1979), originally Bondy, was born into a CzechJewish family in Ostrava. He studied law and became a lawyer. His promising career came to an abrupt end after the beginning of World War II. In 1942, his whole family, among them his wife and his two little daughters, was deported to Theresienstadt and later, in 1944, to Auschwitz-Birkenau. There, Bondy witnessed his family being murdered in the gas chamber, whereas he himself was selected for forced labour in the concentration camps of Monowice and Buchenwald. In April 1945 he was liberated near Jena. After the war, Bor married again and took up a post in the Czechoslovak Ministry of Defence. In the beginning of the 1950s, in connection with the Slánský trial, Bor got into political trouble and lost his employment in the ministry. After several positions in Košice and Prague he started his literary career in the early sixties. In 1966, he retired due to his health. Up to his death, Bor devoted himself to the dialogue between Christians and Jews.

Further Important Publication: Opuštěná panenka (1961, $\rightarrow$ The Abandoned Doll; novel).

\section{Content and Interpretation}

Compared with his novel $\rightarrow$ The Abandoned Doll, which is characterised by a vast richness of details Bor's second work, The Terezín Requiem, is a typical novella, narrowed down to a single plot line. The story is inspired by events that really occurred in Theresienstadt: the rehearsal and presentation of Giuseppe Verdi's Messa di Requiem (1874) by the Jewish conductor Rafael Schächter. Schächter belonged to a large number of intellectuals, artists, scientists and other prominent persons who were detained at the Theresienstadt Ghetto. Born in 1905, the renowned pianist and conductor, founder (1937) and head of the Prague Chamber Opera, came to Theresienstadt at the end of 
1941. In the years up to his deportation to Auschwitz in 1944, where he was murdered by the Nazis, he realised several musical projects, among them the production of Smetana's opera The Bartered Bride as well as Verdi's Requiem. Schächter's Requiem-project met with fierce resistance from the Jewish community. It was the very genre of a Medieval Catholic mass for the deceased that aroused opposition. But Schächter insisted on his intention, seeing in the requiem less of a religious work than a work of art, a masterpiece of high aesthetic and ethical values - values being diametrically opposed to the barbarism and primitivism of the Nazis and their ideology.

This notion obviously provided Schächter with the power to not get discouraged when faced with the numerous setbacks that he received in the process of the rehearsal and presentation of Verdi's Requiem. One of the performances was a special one organised for the members of the International Red Cross who should have been - as a diversionary tactic - led to believe that there was a flourishing, prosperous life among the Jews in the Theresienstadt Ghetto (see Goldflam's $\rightarrow$ Sweet Theresienstadt). Several Nazi officials also participated in this special performance. According to Bor's Requiem, Adolf Eichmann also took part at this performance but it was the author's poetic license.

After his success with The Abandoned Doll, Bor having been a Theresienstadt detainee at the same time as Schächter, was encouraged to write a literary work about this matter by Karel Berman. Berman was a Prague bass singer and Holocaust survivor who had been one of the soloists in Schächter's Requiem performance (cf. Dobeš, 1965, p. 4).

The Terezin Requiem is a novella presented by a non-diegetic narrator who mostly takes up the viewpoint of Rafael Schächter, the work's protagonist. The text focuses on the pivotal moments in the process of Schächter's artistic realisation of the $R e$ quiem, the action thus gaining density and dynamics. The connection of narrative objectivity and subjective perception of the protagonist, i.e. Schächter's thoughts and feelings, affects a characteristic tension between the work's descriptive and emotional level. According to the concept of selection and brevity, typical for the genre of the novella, in the beginning, the historical context is outlined in a few words. It is the summer of 1944, when Germany's defeat in the war was already clear, the Wehrmacht was retreating from all fronts, but Adolf Eichmann was stubbornly clinging to his plans for what he called the "Final Solution of the Jewish question" and even accelerated the Holocaust machinery. For Eichmann, Theresienstadt with its cultural life seemed like the perfect illusion to deceive the world about the proceeding genocide.

In the beginning of the narration a lot of people crowding into the sports hall of the former Theresienstadt school right before the première of the Requiem are seen. From here the perspective changes to the conductor, who, with the orchestra beginning to play, immerses himself in his memory recalling such steps like his decision to perform the Requiem, the assembly of the team (choir, soloists and orchestra) and the artistic and organisational problems connected with it, the difficult acquisition of the instruments (partly by smuggling), the interruptions and setbacks caused by the fact 
that parts of the team were sent to the transports. Readers learn to appreciate Schächter as an assertive, strong-willed person who tenaciously manages to deal with all these problems, thereby always giving the highest priority to his maximalist artistic claims. When the premiere has come to its end the audience's answer is thunderous applause. Schächter, however, is not quite content, because he feels that the final part of the requiem called Libera me ("Deliver me") cannot be interpreted in the sense of the Christian promise of Salvation under the terms of a concentration camp and threatening extermination.

All the more, Schächter feels challenged to continue working on perfecting his interpretation of Verdi's Requiem. These efforts receive an additional stimulus by the plans of the camp commander to give a special presentation of the Requiem during the upcoming visit of Eichmann and other prominent Nazis. Under these premises Schächter tries a new interpretation of the Requiem: a manifestation of accusation and protest. When this special presentation takes place, the whole ensemble works itself up to an expression of wrath and anger, emotions they now can, in a sense, shout directly into their enemies' faces:

Libera me! Everywhere the bells pealed in answer. Libera me! resounded the voices of the choir. Deliver us! Deliver us! clamoured from all sides altos and tenors, sopranos and basses. We want liberty! the orchestra replied to them. And the kettle-drums rolled and thundered: Libera nos! Libera nos! (Bor, 1963, p. 81).

Here, Schächter's artistic efforts have fully achieved their goal. Eichmann and the other Nazis are impressed and baffled at once. But their ideology lacks the ability of self-reflection as well as ethical and aesthetic standards. This means that nothing changes, as true communication between the performers (the victims) and the audience (the perpetrators) it fails. Communication between artistic perfection and banality or degeneracy is simply impossible. The novella ends in disillusionment:

The summer drew to its close, and the time of the transports began again. The Command had promised that Schächter's company should not be separated. The promise was kept. All together they ascended into the first wagons of the first transport (p. 83).

\section{Main Topics and Problems}

Bor builds his novella around a framework of situations which in a sense all refer to the perception, interpretation and understanding respectively non-understanding of art. The text is focused on Schächter's persistent struggle for the "right" interpretation of Verdi's Requiem. In doing so he comes to realise that it is not sufficient, under the extreme conditions of the Holocaust with its permanent presence of the degradation of human dignity and the proximity of death, to believe in the ethical power of art as a counterforce. The inhuman situation of the ghetto or camp requires instead the use of art for the expression of protest or even rebellion. This is the difference between Schächter's first interpretation of the Requiem which he was dissatisfied with, and his 
second interpretation, to which he comes after recognising the potential hidden in the subtext of the work. He arouses this potential during the second performance in direct confrontation with the Nazi audience, although this can only function on a symbolic level, as the conditions for equal communication between artists and audience are not given. So, the complexity of the artistic process under extreme conditions is one of the dominant themes of the work.

A comparison of the novella with the real events around Schächter's Requiem-project having taken place in 1943 and 1944 shows that Bor considerably modified the real events in his text. For example, in the actual performances the choir was accompanied only by piano. In the novella's plot there is, however, an entire orchestra with instruments having largely been smuggled into the ghetto from outside. We actually know about such smuggling activities, but not in the context of Schächter's rehearsal and presentation of Verdi's Requiem (Ibler, 2016, p. 211). As one might say, Bor makes use of the authentic facts of Theresienstadt reality, from which he creates the artistic reality of his novella by means of selection and combination. This can also be seen in other parts of the work. In reality, Schächter had assembled his ensemble, due to the losses of members by transports, altogether three times with the last ensemble giving even 15 performances (pp. 211ff.). In the novella, however, there are only two ensembles with altogether two performances. The fact that in the last performance members of the International Red Cross were present, is never mentioned in the literary text, there is only talk of a special performance for the Nazi notables (p. 212). Such a literary motivated reduction focuses attention on the central concern of the work: to demonstrate the superiority of morality and beauty over banality and violence by the victims directly confronting the perpetrators. Thus, the modifications made by Bor are by no way a means to ignore or even manipulate historical truth, but they aim at focussing on a higher, moral and aesthetic truth created by the power of art.

\section{Cited Works}

Bor, J. (1963). The Terezín Requiem. London: Heinemann. dk (=Dobeš, K.). (1965). A tu nemohl jsem mlčet... Pět minut hovoru a dlouhá doba mlčení s Josefem Borem. Svobodné slovo, 21(72), 14. 3., p. 4. Ibler, R. (2016). Zwischen Dokument und Kunst: Josef Bors Werke über den Holocaust. In: R. Ibler, ed., The Holocaust in the Central European Literatures and Cultures: Problems of Poetization and Aestheticization. Stuttgart: ibidem, pp. 203-215.

\section{Further References}

Bolton, J. (2004). Josef Bor (Bondy). In: E. Sicher, ed., Holocaust Novelists. Detroit: The Gale Group, pp. 58-64. Ibler, R. (2017). Kunst im Holocaust. Zu Josef Bors Novelle Terezínské rekviem und ihrer Rezeption. Poznańskie Studia Slawistyczne, (12), pp. 167179. Karas, J. (1985). Music in Terezin: 1941-1945. New York: Beaufort Books. Kissen, R. M. (2008). The Terezín Requiem. In: J. K. Roth, ed., Holocaust Literature, vol. 1. Pasadena: Salem Press, pp. 503-507. Klíma, C.A. (2019). The Terezín Requiem. Available at: 
https://www.encyclopedia.com/arts/encyclopedias-almanacs-transcripts-and-maps/ terezin-requiem-terezinske-rekviem [Accessed: 05.10.2019]. Kuna, M. (1993). Musik an der Grenze des Lebens. Musikerinnen und Musiker aus den böhmischen Ländern in nationalsozialistischen Konzentrationslagern und Gefängnissen. Frankfurt: Zweitausendeins. Lauermann, M., Waageová, E. (2019). JuDr. Josef Bor. Available at: https:// www.holocaust.cz/dejiny/lide/obeti/judr-josef-bor/ [Accessed: 04.10.2019]. Schreiner, S. (2007). „Seine Taten sind sein Denkmal“. Orientierung, 71(1), pp. 1-4. Udolph, L. (2003). Josef Bors Terezínské rekviem (1963). In: W. Schmitz, ed., Erinnerte Shoah. Die Literatur der Überlebenden. Dresden: Thelem, pp. 326-337.

RI 